\title{
ANALISIS KESALAHAN PENYUSUNAN TES PILIHAN GANDA SOAL UJIAN AKHIR SEKOLAH MATAPELAJARAN BAHASA INDONESIA SMA DAN SMP YAYASAN SERI AMAL TAHUN AJARAN 2020/2021
}

\author{
Losten Tamba \\ FKIP Universitas Santo Thomas Medan \\ Email: losten.tamba@gmail.com
}

\begin{abstract}
ABSTRAK
Penelitian ini dilakukan untuk mengetahui atau menganalisis kesalahan penyusunan tes pilihan ganda matapelajaran bahasa Indonesia yang digunakan dalam ujian akhir semester kelas 9 dan kelas 12. Penelitian dilakukan pada bulan Maret-April 2021 kepada naskah soal pilihan ganda matapelajaran Bahasa Indonesia yang berjumlah 60 butir soal. Sebelum soal dianalisis secara deskriptif, butir soal dianalisis berdasarkan proporsi distracter untuk mengetahui butir soal yang tidak baik. Soal yang tidak baik dianalisis berdasarkan materi, konstruksi, dan bahasa.
\end{abstract}

Kata kunci: analisisis kesalahan, tes pilihan ganda, soal ujian akhir sekolah

\begin{abstract}
This study was conducted to find out or analyze the errors in the preparation of the multiple choice test for Indonesian subjects used in the final exams for the 9th and 12th semesters. The study was conducted in March-April 2021 on the multiple choice questions in Indonesian subjects, which consisted of 60 questions. Before the questions were analyzed descriptively, the items were analyzed based on the proportion of distracters to find out which items were not good. Problems that are not good are analyzed based on material, construction, and language.
\end{abstract}

Keywords: error analysis, multiple choice test, final school exam questions

I. LATAR BELAKANG

Penilaian sangat penting dalam kegiatan pembelajaran. Dengan penilaian, guru dapat mengetahui berbagai hal sebagai dampak dari proses dan hasil pembelajaran. Secara umum, penilaian dapat mengukur hasil belajar dalam setiap aspek yaitu kognitif, afektif, dan psikomotor sehingga guru dapat mengetahui tingkat keberhasilan belajar sehingga dapat mengambil keputusan untuk melakukan perbaikan dari setiap komponen pembelajaran seperti tujuan, metode, media, dan sebagainya. Selain itu, penilaian dapat berfungsi efektif dalam melakukan seleksi, penempatan siswa secara tepat, dan untuk mengetahui kelemahankelemahan belajar siswa. 
Untuk melakukan penilaian kognitif, afektif, dan psikomotor, ada banyak teknik dan istrumen yang dapat digunakan. Penggunaan teknik dan istrumen penilaian dengan mempertimbangkan sejumlah aspek sehingga dapat digunakan secara tepat untuk mendapatkan data atau nilai yang akurat sehingga dapat digunakan untuk mengambil keputusan yang tepat. Aspek yang harus diperimbangkan dalam pemilihan alat penilaian adalah tipe hasil belajar yang akan diukur. Ketepatan teknik dan instrumen dengan aspek yang akan diukur berkaitan dengan kesahihan penilaian.

Penilaian aspek kognitif untuk mengukur hasil belajar menggunakan tes tertulis, tes lisan, dan penugasan. Tes tertulis mencakup tes pilihan ganda (dengan berbagai jenisnya), tes benar salah, tes menjodohkan, tes melengkapi (jawaban singkat) dan tes uraian (esei). Tes lisan adalah tes yang disampaikan secara lisan dengan membuat pertanyaan yang diajukan secara langsung kepada peserta didik untuk mengukur atau mengetahui pencapaian hasil belajarnya. Tes penugasan yaitu tes yang diberikan oleh guru berkaitan dengan aspek yang diajarkan untuk dikerjakan di rumah sebagai tugas individu atau tugas kelompok.

Tes pilihan ganda merupakan tes yang paling banyak dan paling sering digunakan untuk untuk mengukur berbagai aspek hasil belajar kognitif karena tes ini memiliki sejumlah keunggulan dibandingkan dengan tes tulis lain. Selain penilaiannya objektif, tes ini dapat mengukur berbagai tingkat kognitif, mulai dari yang paling rendah sampai tingkat kognitif paling tinggi (kompleks). Tes ini juga dapat mengukur bahan atau materi pembelajaran yang sangat luas sehingga penilaian mencakup keseluruhan materi secara representatif. Tes ini dapat digunakan berulang-ulang oleh orang yang berbeda-beda untuk mengukur hasil belajar yang berkaitan dengan isi tes tersebut.

Untuk mendapatkan hasil penilaian yang bermutu, tes pilihan ganda harus dibuat dan disusun sedemikian rupa dengan memperhatikan proses penyusunan tes tersebut dengan tepat. Penyusunan tes pilihan ganda haurs mempertimbangkan aspek materi, konstruk, dan bahasa. Aspek materi mencakup representasi materi yang diujikan, ketepatan soal dengan indikator, dan homogenitas aspek yang diuji. Konstruk berkaitan dengan kejelasan, efektivitas, dan ketegasan pokok soal, panjang soal, dan urutan pilihan soal (option). Bahasa menyangkut ketetapan bentuk kata, diksi, efektivitas kalimat, dan penggunaan ejaan yang tepat. Pengukuran kualitas tes, khususnya pilihan ganda, dapat dilakukan secara kualitatif seperti dijelaskan sebelumnya dan secara kuantitatif seperti analisis validitas, reliabilitas, daya beda (diskriminasi), tingkat kesukaran, dan pengukuran proporsi distracters. Penelitian ini menggunakan proporsi distracters untuk mengukur kualitas tes soal ujian akhir sekolah matapelajaran 
bahasa Indonesia buatan guru SMA dan SMP di Yayasan Seri Amal Medan tahun ajaran 2020/ 2021.

\section{KERANGKA TEORI}

\section{Konsep Analisis Kesalahan}

Secara etimologis, kata analisis berasal dari bahasa Latin yaitu analusis yang artinya melepaskan. Kata analusis berasal dari dua kata yaitu ana berarti kembali dan luein artinya melepas. Kamus Besar Bahasa Indonesia (KBBI), analisis adalah (1) penyelidikan terhadap suatu peristiwa (karangan, perbuatan, dan sebagainya) untuk mengetahui keadaan yang sebenarnya (sebab musabab, duduk perkara, atau hal-hal lainnya), (2) penguraian suatu pokok atas berbagai bagian itu sendiri serta hubungan antarbagian untuk memperoleh pengertian yang tepat dan pemahaman arti keseluruhan (2008: 58). Menurut Soedjadi (1995), analisis adalah rangkaian kegiatan pemikiran logis, rasional, sistematis, dan obyektif, dengan menerapkan metodologi atau teknik ilmu pengetahuan untuk melakukan pengkajian, penelaahan, penguraian, pemerincian, dan pemecahan terhadap suatu obyek atau sasaran sebagai satu kebulatan komponen yang utuh ke dalam subkomponen-subkomponen yang lebih kecil sehingga dapat diperoleh kejelasan tentang fakta, data, dan informasi dari obyek tersebut (Arfah Maulida, 2018: 26-27). Kesalahan adalah penyimpangan dari hal yang sudah diketahui kebenarannya. Analisis kesalahan yaitu analisis terhadap penyimpangan yang terdapat pada sesuatu hal dari yang sebenarnya. Analisis dibuat untuk mengetahui keberadaan sesuatu secara objektif kemudian dibandingkan suatu ukuran.

\section{Tes Pilihan Ganda}

Tes pilihan ganda terdiri dari dari suatu masalah pokok (stem) yang diiringi beberapa pilihan (alternatif) yang merupakan jawaban atas masalah pokok tersebut. Stem dapat berupa pertanyaan atau pernyataan tidak lengkap. Butir alternatif mencakup jawaban yang benar dan beberapa jawaban yang salah yang disebut pengalih perhaatian (distracters). Tes pilihan ganda dapat digunakan untuk mengukur pengetahuan dan berbagai jenis keterampilan intelektual. Tes pilihan ganda dapat mengukur pengetahuan mengenai istilah, konvensi, kecenderungan, klasifikasi/ kategori, kriteria metodologi, prinsip/generalisasi, teori dan struktur.

Ketentuan menyusun tes pilihan ganda: (a) Butir pertanyaan mengukur hasil belajar yang dianggap penting (sampel representatif); (b) Rumusan dan sasaran stem harus jelas, (c) Masukkan sebagian besar kata-kata dalam stem, (d) Sedapat mungkin, buat stem dalam bentuk pertanyaan positif, jika tidak, tandai kata negatif dalam stem tersebut, (e) Harus dipastikan bahwa jawaban adalah benar atau yang terbaik, (f) Bahasa stem dan pilihan harus koheren, (g) Hindarkan petunjuk yang memungkin peserta didik memilih jawaban yang benar, (h) Isi dan bentuk (panjang) jawaban relatif sama (homogen), (i) Buatlah pengalih perhatian seakan-akan benar, (j) Hindarkan penggunaan pilihan "semua 
benar/salah", (k) Buatlah jawaban secara random, (l) Urutan pilihan logis, dan (m) Usahakan butir pertanyaan berdiri sendiri.

Telaah soal keterampilan berpikir tinggi bentuk tes pilihan ganda dapat dilihat atau diukur dari aspek:

a. Materi

1) Soal sesuai dengan indikator.

2) Soal menggunakan stimulus yang menarik (baru, mendorong, siswa untuk membaca).

3) Soal menggunakan stimulus yang kontekstual.

4) Soal mengukur level kognitif penalaran (menganalisis, mengevaluasi, mencipta).

5) Jawaban tidak ditemukan pada stimulus.

6) Tidak rutin dan mengusung kebaruan.

7) Pilihan jawaban homogen dan logis.

8) Setiap soal hanya ada satu jawaban yang benar.

b. Konstruksi

1) Pokok soal dirumuskan dengan singkat, jelas, dan tegas.

2) Rumusan pokok soal dan pilihan jawaban merupakan pernyataan yang diperlukan saja.

3) Pokok soal tidak memberi petunjuk ke kunci jawaban.

4) Pokok soal bebas dari pernyataan yang bersifat negatif ganda.

5) Gambar, grafik, tabel, diagram, atau sejenisnya jelas dan berfungsi.

6) Panjang pilihan jawaban relatif sama.

p-ISSN 2648-8600

e-ISSN 2745-410X

Volume 4 Nomor 1 Juni 2021
7) Pilihan jawaban tidak menggunakan pernyataan "semua jawaban di atas salah" atau "semua jawanban di atas salah", dan seterusnya.

8) Pilihan jawaban yang berbentuk angka/waktu disusun berdasarkan urutan besar kecilnya atau kronologisnya.

9) Butir soal tidak bergantung pada jawaban soal lain.

c. Bahasa

1) Menggunakan bahasa yang sesuai dengan kaidah bahasa Indonesia.

2) Tidak menggunakan bahasa yang berlaku setempat.

3) Soal menggunakan kalimat yang komunikatif.

4) Pilihan jawaban tidak mengulang kata/ atau kelompok kata yang sama, kecuali merupakan satu kesatuan pengertian.

\section{Asesmen Kompetensi Minimal}

Asesmen merupakan kegiatan untuk mengungkapkan kualitas proses dan hasil pembelajaran. Kompetensi minimum adalah kompetensi yang benar-benar minimum atau dasar yang sangat diperlukan siswa (literasi dan numerasi) untuk mempelajari semua materi pembelajaran. Asesmen Kompetensi Minimum (AKM) adalah penilaian kompetensi yang sangat diperlukan siswa (literasi dan numerasi) untuk mempelajari materi pembelajaran. Tujuan penulisan desain pengembangan soal AKM adalah menyusun rancangan pengembangan soal AKM agar memberikan gambaran 
utuh mengenai kerangka, framework, dan pemanfaatan soal-soal AKM melalui survei nasional, survei kelas, maupun sertifikasi.

Ruang lingkup pengembangan soal AKM meliputi numerasi dan literasi membaca peserta didik di kelas 2, 4, 5, 6, 8, 10, dan 11. Pengembangan soal dibagi ke dalam 6 level, yaitu level 1 (kelas 1-2), level 2 (kelas 3-4), level 3 (kelas 5-6), level 4 (kelas 7-8), level 5 (kelas 9-10), dan level 6 (kelas 11-12). Setiap kompetensi yang diukur dalam setiap level dituangkan ke dalam framework literasi dan numerasi. Pada literasi membaca terdapat kompetensi dan subkompetensi dengan peningkatan kompetensi sesuai dengan jenjang/level, sedangkan pada numerasi terdapat domain dan subdomain dengan disertai level kognitif yang perlu dikuasai peserta didik pada setiap level.

a. AKM Literasi

Literasi membaca adalah kemampuan untuk memahami, menggunakan, mengevaluasi, merefleksikan bentuk-bentuk teks tertulis yang dibutuhkan oleh masyarakat dan/atau dihargai oleh individu. Untuk kepentingan penyusunan soal AKM, konten teks dikelompokkan menjadi dua yaitu teks sastra dan teks informasi. Melalui teks sastra peserta didik dapat memperoleh hiburan, menikmati cerita, dan melakukan perenungan untuk menghayati permasalahan kehidupan yang ditawarkan pengarang. Di sisi lain, melalui teks informasi peserta didik dapat memperoleh fakta, data, dan informasi untuk pengembangan wawasan dan ilmu pengetahuan yang bersifat ilmiah.

AKM literasi memiliki konteks. Konteks sangat penting sehingga peserta didik dapat memahami, mengenali, dan menggunakan informasi untuk memperkaya pengetahuannya, baik sebagai individu maupun bagian dari masyarakat (sosial) yang selalu berkembang sesuai dengan perkembangan ilmu pengetahuan dan teknologi. Bahan bacaan literasi AKM dapat mencakup tiga konteks yaitu konteks personal, konteks sosialbudaya, dan konteks saintifik. Level kognitif literasi membaca yang diujikan adalah menemukan informasi, memahami, dan mengevaluasi dan merefleksi.

\section{b. AKM Numerasi}

Numerasi adalah kemampuan berpikir menggunakan konsep, prosedur, fakta, dan alat matematika untuk menyelesaikan masalah seharihari pada berbagai jenis konteks yang relevan untuk individu sebagai warga negara Indonesia dan dunia. Numerasi dimaknai sebagai kemampuan yang dimiliki oleh seseorang dalam menggunakan pengetahuan matematika yang dimilikinya dalam menjelaskan kejadian, memecahkan masalah, atau mengambil keputusan dalam kehidupan sehari-hari. Hal ini dapat membantu peserta didik mengenali peran matematika dalam kehidupan nyata sehingga dapat membuat penilaian dan keputusan yang diperlukan serta 
menjadi manusia bertanggung jawab yang mampu bernalar/berpikir logis.

Konteks yang luas sangat penting digunakan pada AKM numerasi sehingga peserta didik dapat mengenali peran matematika dalam kehidupan sehari-hari. Konteks dalam AKM numerasi mencakup konteks yang dekat dengan dunia peserta didik, sosial, budaya, lingkungan, sains, maupun keilmuan matematika. Konteks-konteks tersebut dikategorikan menjadi tiga, yaitu personal, sosial-budaya, dan saintifik.

AKM mengharuskan peserta didik menggunakan berbagai keterampilan kognitif dalam menjawab soal-soal. Level kognitif numerasi AKM dibagi menjadi tiga level yaitu (a) knowing yaitu soal dalam level kognitif ini menilai kemampuan pengetahuan peserta didik tentang fakta, proses, konsep, dan prosedur, (b) applying (penerapan) yaitu soal pada level kognitif ini menilai kemampuan matematika dalam menerapkan pengetahuan dan pemahaman tentang fakta-fakta, relasi, proses, konsep, prosedur, dan metode pada konteks situasi nyata untuk menyelesaikan masalah atau menjawab pertanyaan, dan (c) Reasoning (penalaran) soal dalam level kognitif ini menilai kemampuan penalaran peserta didik dalam menganalisis data dan informasi, membuat kesimpulan, dan memperluas pemahaman mereka dalam situasi baru, meliputi situasi yang tidak diketahui sebelumnya atau konteks yang lebih kompleks. Pertanyaan dapat mencakup lebih dari satu pendekatan atau strategi. Konten domain AKM numerasi ada empat yaitu bilangan, numerasi, geometri dan pengukuran, aljabar, serta data dan ketidakpastian.

\section{Higher Order Thinking Skill (HOTS)}

Berpikir merupakan suatu kegiatan mental yang terjadi ketika seseorang dihadapkan pada situasi atau suatu permasalahan yang harus diselesaikan. Kegiatan mental atau kegiatan berpikir yang terjadi dapat berbeda-beda tingkatannya tergantung pada situasi atau kompleksitas masalah yang dihadapi. Suatu masalah mungkin dapat diselesaikan dengan tingkat berpikir yang lebih rendah seperti mengingat dan memahami, namun dapat juga diselesaikan dengan tingkat berpikir tinggi seperti menganalisis dan mengevaluasi. Menurut Susan Brookhart (Tim Pusat Penilaian, 2019: 3 ), ada tiga proses berpikir tingkat tinggi yaitu menganalisis, mengevaluasi, dan mengkreasi.

Soal HOTS adalah soal yang dikerjakan dengan tingkat berpikir tinggi yaitu (a) transfer satu konsep ke konsep lainnya, (b) memproses dan menerapkan informasi, (c) mencari kaitan dari berbagai informasi yang berbeda-beda, (d) menggunakan informasi informasi untuk menyelesaikan masalah, (e) menelaah ide dan informasi secara kritis. Dilihat dari dimensi pengetahuan, soal HOTS mengukur dimensi metakognitif yang menggambarkan kemampuan menghubungkan beberapa konsep yang 
berbeda, menginterpretasikan, memecahkan masalah, memilih strategi pemecahan masalah, menemukan metode baru, berargumen, dan mengambil keputusan yang tepat.

Dalam penyusunan penilaian berpikir tingkat tinggi, terdapat tiga hal yang perlu diperhatikan yaitu (a) menggunakan stimulus, (b) menggunakan konteks baru, dan (c) membedakan antara tingkat kesulitan dan kompleksitas proses berpikir. Prinsip penyusunan HOTS yaitu (a) menentukan secara jelas apa yang akan dinilai, (b) menyusun tugas atau soal tes yang harus dikerjakan, dan menentukan kriteria penguasaan hal yang dinilai dari hasil pelaksanaan tugas atau tes.

\section{METODE PENELITIAN}

Penelitian dilakukan pada bulan April 2021 pada soal ujian akhir sekolah SMA kelas XII dan SMP kelas IX yang terdiri dari dua paket soal yaitu soal utama dan soal susulan. Soal terdiri dari 60 butir soal pilihan ganda yaitu $25 \%$ soal Asesmen Kompetensi Minimal (AKM) untuk literasi/ numerasi dan 75 $\%$ non-AKM. Non-AKM terdiri dari 25 $\%$ LOTS dan $75 \%$ HOTS. Soal pilihan ganda untuk SMA terdiri dari lima option dan soal SMP terdiri dari empat option. Soal dibuat dalam bentuk google form dan diujikan secara vitual dalam waktu 120 menit. Soal dianalisis berdasarkan materi, konstruksi, dan bahasa dalam penyusunan soal pilihan ganda.

\section{HASIL PENELITIAN}

p-ISSN 2648-8600

e-ISSN 2745-410X

Volume 4 Nomor 1 Juni 2021
Berdasarkan analisis tes dengan perhitungan proporsi distracter ditemukan bahwa ada $25 \%$ jumlah soal yang kurang baik karena option dalam butir tes tersebut ada yang dipilih responden kurang dari 5\%. Soal yang kurang baik tersebut dapat dilihat dari konstruksi, materi, dan bahasa:

1. Setelah di-crossceck antara soal yang dibuat dengan kartu ujian, ada permasalahan dalam beberapa butir soal tidak sesuai dengan indikator yang dirumuskan berkaitan dengan soal yang dujikan kepada siswa. Misalnya, dalam indikator disebutkan "siswa dapat membedakan demokrasi terpimpin dengan demokrasi liberal" namun yang diujikan adalah konsep demokrasi terpimpin. Hal ini berdampak pada perbedaan level kognitif yang diujikan.

2. Stimulus yang dibuat pada umumnya tidak kontekstual dan menarik, lebih banyak menyangkut peristiwa atau permasalahan yang sudah sudah lama dan tidak berkaitan dengan kehidupan siswa atau masyarakat lingkungan siswa. Selain itu, stimulus tersebut sering mubazir, kalimat-kalimatnya tidak efektif karena tidak koheren dan tidak jelas. Aga gambar, grafik, tabel, diagram, dan sejenisnya tidak berfungsi karena pertanyaan tidak berkaitan dengan isi gambar tersebut.

3. Ada beberapa butir soal, di mana jawaban pada pilihan butir soal secara jelas (tersurat) ada dalam 
stimulus atau konteks butir soal. Ketika hal ini disampaikan kepada penyusun soal, mereka selalu mengaitkannya dengan soal literasi

4. Pilihan soal dalam butir soal sering tidak homogen, menanyakan permasalahan yang berbeda, bahkan menyangkut hal yang kontradiksi sehingga siswa dapat memilih dengan mudah jawaban yang benar dan tidak lagi mempertimbangkan pilihan lain Jadi, ada pilihan yang tidak berfungsi sebagai pengecoh (distracter). Ketidak-homogenan dalam pilhan soal membuat soal tidak logis karena pilihannya berisikan hal, materi, atau permasalahan yang berbeda.

5. Ada beberapa butir soal di mana pilihannya terlalu dipaksakan sehingga membuat pilihan yang tidak relevan, bahkan ada pilihan "semua benar atau salah".

6. Ada beberapa butir soal, di mana pilihannya tidak disusun secara logis. Misalnya, jika pilihan dalam bentuk angka maka harus disusun dari yang terkecil menunjuk yang lebih besar, atau bisa disusun secara kronologis, spasial, kedekatan, dan sebagainya.

7. Beberapa butir soal memiliki pilihan yang panjangnya sangat berbeda. Ada pilihan yang hanya dua kata, sementara pilihan lain ada lebih dari lima kata. Perbedaan panjang pilihan ini kerapkali menjadi petunjuk bagi siswa untuk memilih jawaban yang benar.
8. Dari soal yang diujikan, ada beberapa soal di mana penggunaan bahasa dalam penyataan atau pertanyaan (stem) tidak koheren dengan pilihan. Hal ini juga menjadi hal dapat mempermudah bagi siswa untuk menebak jawaban yang benar.

9. Pengerjaan beberapa butir soal tergantung dari butir soal yang lain. Artinya, butir soal tertentu dapat dikerjakan setelah diekrjakan butir soal lain. Hal ini juga berdampak ketepatan dalam pengerjaan soal. Karena itu, butir soal seharusnya berdiri sendiri.

10. Ada beberapa soal di mana kalimat pilihan sangat panjang, bahkan dibuat dalam bentuk paragraf. Karena itu, jauh lebih baik jika sebagian besar kata-katanya dimasukkan dalam stem sehingga pilihannya menggunakan bahasa yang hemat.

11. Beberapa pernyataan, pertanyaan, atau stem menggunakan bahasa yang tidak hemat, urutannya tidak tepat, pilihan kata yang tidak tepat, dan penggunaan ejaan yang salah.

\section{KESIMPULAN DAN SARAN}

1. Kesimpulan

a. Hasil analisis tes dengan perhitungan proporsi distracter ditemukan bahwa ada $25 \%$ jumlah soal yang kurang baik karena option dalam butir tes tersebut ada yang dipilih responden kurang dari $5 \%$.

b. Kesalahan yang ditemukan dalam pembuatan soal pilihan ganda ujian 
akhir sekolah SMP dan SMA Yayasan Seri Amal Medan berkaitan dengan materi, konstruksi, dan bahasa. Kesalahan itu pada umumnya karena option tidak berfungsi dengan baik karena tidak homogen, logis, kejelasan stimulus, dan penggunaan bahasa yang kurang tepat.

2. Saran

a. Soal ujian yang digunakan hendaknya selalu dianalisis sehingga dapat diketahui kualitasnya.

b. Perlu ada pelatihan penyusunan soal bagi guru-guru sehingga dapat mengenal dan membuat soal pilihan ganda dengan tepat.

\section{DAFTAR PUSTAKA}

Arikunto, Suharsimi. Dasar-dasar Evaluasi Pendidikan. Jakarta: Bumi Akasara, 2005.

Direktorat Pembinaan Sekolah Menengah Atas Direktorat Jenderal Pendidikan Dasar dan Menengah Kementerian Pendidikan dan Kebudayaan. Modul Penyusunan Soal Higher Order Thinking Skill (HOTS), 2017.

Direktorat Jenderal Pendidikan Dasar dan Menengah Direktorat Pembinaan Sekolah Menengah Atas Kementerian Pendidikan dan Kebudayaan. Modul Penyusunan Soal Keterampilan Berpikir Tingkat
Tinggi (Higher Order Thinking Skill), 2019.

Febriana, Rina. Evaluasi Pembelajaran. Jakarta: Bumi Akasara, 2019.

Pusat Asesmen dan Pembelajaran Badan Penelitian dan Pengembangan dan Perbukuan Kementerian Pendidikan dan Kebudayaan. Desain Pengembangan Soal AKM, 2020.

Pusat Bahasa Departemen Pendidikan Nasional. Kamus Besar Bahasa Indonesia. Jakarta: PT Gramedia Pustaka Utama, 2008.

Pusat Penilaian Pendidikan Badan Penelitian dan Pengembangan Kementerian Pendidikan dan Kebudayaan. Panduan Penulisan Soal HOTS (Higher Order Thinking Skill), 2019.

Sudijono, Anas. Pengantar Evaluasi Pendidikan (cetakan ke-13) . Jakarta: PT Raja Grafindo Persada, 2013. 